\title{
PERFORMANCE EVALUATION OF A LOCALLY MACHINE FOR CHOPPING OF ONION RESIDUES
}

\author{
R. A. Werby $^{(1)}$ and A. M. Mousa ${ }^{(2)}$
}

\section{ABSTRACT}

Crops residues are one of the most critical problems, which face the Egyptian farmer especially after harvesting process. The present study was carried out to evaluate of the performance efficiency of stationary threshing and separating machine of wheat crop (locally manufactured); this machine was used to cutting and chopping of onion crop residues (leafs) with the desired cutting lengths for different uses. The used machine was tested and evaluated at chopping drum speeds of 350, 450, 550 and $650 \mathrm{rpm}$ and feeding rates $5,10,15$ and $20 \mathrm{~kg} / \mathrm{min}$ with two moisture contents of 11.5 and $17.6 \%$ under air speed of $6 \mathrm{~m} / \mathrm{s}$. The results showed that; the stationary thresher machine can be successfully used for cutting and chopping of onion leafs under the following optimum conditions: $650 \mathrm{rpm}$ for drum speed, $20 \mathrm{~kg} / \mathrm{min}$ for feeding rate and the percentages of cutting length (less than $30 \mathrm{~mm}$ ) were 42 and $23 \%$ for two tested moisture contents of 17.6 and $11.5 \%$, respectively, also; the power consumption and specific energy requirement were found to be (14.1 and $23.9 \mathrm{~kW})$ and $(12.5$ and $21.5 \mathrm{~kW} . \mathrm{h} / \mathrm{Mg}$ ) for two tested moisture contents of 17.6 and $11.5 \%$, respectively. In addition to; analysis of onion leafs samples with two tested moisture contents of 17.6 and $11.5 \%$ showed that the protein contents were 10.85 and $9.97 \%$ and fat contents were 1.75 and $6.19 \%$, respectively. The maximum operation costs were $86.28 \mathrm{LE} / \mathrm{h}$ and $76.48 \mathrm{LE} / \mathrm{Mg}$.

Keywords: Stationary threshing machine, cutting and chopping, crops residues, onion leafs.

\section{INTRODUCTION}

The amount of crops residues increased all over the world due to increasing in crops production. Annual crops residues were

1 amounted with 40 million tons. The best way to remove the agricultural residues are cutting and chopping for next operation of waste recycling in different industries such as making compost, improvement of

(1): Assoc. Prof. and (2): Lecturer, Ag. Mach. \& Power Eng. Dept., Fac. of Ag. Eng., Al-Azhar Univ., Cairo, Egypt. 
soil properties, animal feeding, as source of renewable energy (direct burning, biogas generation), compressed wood and field of industrial application. Onion is considered as the most important and widely cultivated vegetable in Egypt, due to its high nutrition value. The crop is planted for local consumption or exporting. The total cultivated area of onion crop in Egypt was about 202090 Feddan and producing about 3.12 million $\mathrm{Mg}$ of onion crop; according to, (FAO, 2016).

Onion bulbs are always harvested at complete mature stage with green topping leafs and high moisture content. One of the major problems facing exportation of Egyptian onion is the lower storability characteristics when shipping to the European countries that exposing the bulbs to decay and hence facing rejection from the exporter, (Abd-Elrahman and Ebaid, 2009).

Grahame (2005) and Marita (2006) showed that the curing of bulbs is the process by which the outer leaf sheaths and neck tissues of the bulb then dried. Pandey et al. (1992) reported that the total loss in weight of onion bulbs during a storage period increase with decreasing the maturity stages to $20 \%$ tops down and lowest of onion bulbs was always associated with highest value of average percentage of total loss in onion weight $17.74 \%$.

Hashish et al. (1994) studied some factors affecting the performance of chopping, crushing and grinding equipment for field raw material. They concluded that the optimum speed was found as $9.4 \mathrm{~m} / \mathrm{s}$ for the three tested raw materials cotton, maize stalks and rice straw, the highest production rate and efficiency were obtained at low levels of moisture content of raw materials. Yousf (2005) reported that the power requirement of the grinding operation increased with increasing feeding rates, while it decreased with increasing screen opening size. The best results were obtained at $29.5 \mathrm{~m} / \mathrm{s}$ for hammer speed, $550 \mathrm{~kg} / \mathrm{h}$ for feeding rate and screen opening sizes of $6 \mathrm{~cm}^{2}$.

El-Iraqi and Khawaga (2002) designed and evaluated a machine for cutting crops residues. The maximum percentages of cutting length for 
less than $5 \mathrm{~cm}$ were $87.80 \%$ and $92 \%$ for rice straw and corn stalks residues, respectively. Arfa (2007) modify and evaluated a machine for cutting of crops residues under the following conditions: oval slots area of $4 \mathrm{~cm}^{2}$, drum speed of $18.33 \mathrm{~m} / \mathrm{s}$, feeding rate of $1.5 \mathrm{ton} / \mathrm{h}$, moisture content of $14.3 \%$ and concave clearance of $3 \mathrm{~cm}$. The results showed that the percentages of cutting length (less than $3.5 \mathrm{~cm}$ ) were 82.1, 85.6 and $89.1 \%$ for rice straw, corn stalks and cotton stalks, respectively. The power consumption and specific energy requirement were (43.3, 40.3 and $38.7 \mathrm{~kW})$ and $(28.9,27.3$ and $25.8 \mathrm{~kW} . \mathrm{h} / \mathrm{ton})$ for rice straw, corn and cotton stalks residues, respectively. Luis et al. (1993) found that the cutting lengths of crops residues range between 3 to $7.5 \mathrm{~cm}$ can be used in feeding animals and composting of residues.

The main objective of this research is to testing and performance evaluation of a locally manufactured stationary threshing machine (El-Shams) for shopping of onion residues (leafs) to select the optimum operating parameters; the specific objectives were as follow: Determine the effect of drum speed, feeding rate at two moisture contents of onion leafs 17.6 and $11.5 \%$ (wet basis) on chopping of onion leafs and evaluate of the performance indicators for the used machine: productivity, percentage of cutting length, power consumption and specific energy requirement.

\section{MATERIALS AND METHODS}

The experiments were carried out in Arumon village - Kafr El-Sheikh governorate during 2017 season. The variety of onion used in this study was (Giza 20). The locally manufactured stationary threshing machine (El-Shams) was used in this study and its specifications are shown in Fig.

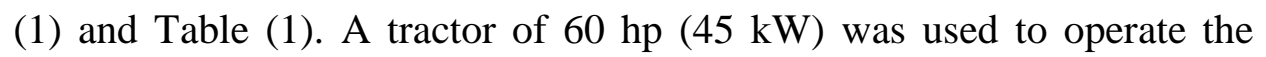
machine and the power was transmitted by means of a belt pulley from a tractor pulley. To achieve the objectives of this research - the following variables were studied: drum speeds (350, 450, 550 and $650 \mathrm{rpm})$ and feeding rates $(5,10,15$ and $20 \mathrm{~kg} / \mathrm{min})$ at two moisture contents of onion leafs $11.5 \%$ and $17.6 \%$ (wet basis), in addition to investigate from effect the previously variables parameters on the productivity, percentage of cutting length, power consumption and specific energy requirement. 


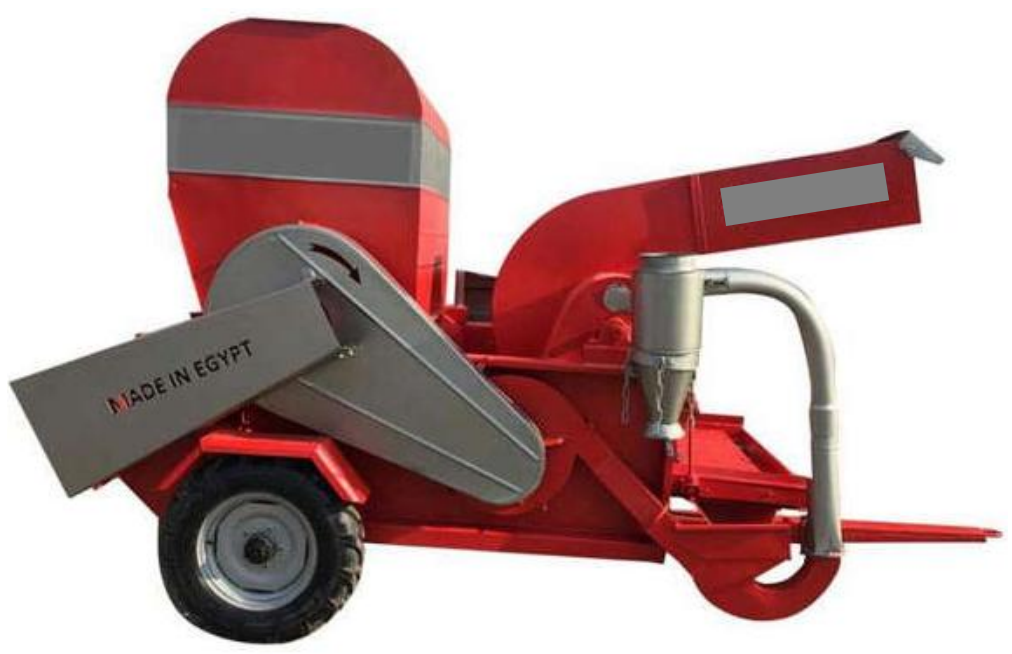

Fig. (1). The used thresher machine to chopping of the onion leafs.

Table (1): Specifications of stationary threshing and separating machine used in chopping of onion leafs.

\begin{tabular}{lc}
\hline Item & Specification \\
\hline Overall dimensions & \\
Length, $(\mathrm{cm})$ & 400 \\
Width, $(\mathrm{cm})$ & 225 \\
Height, $(\mathrm{cm})$ & 225 \\
\hline Method of feeding & Manual \\
\hline Prime mover & Belt \\
\hline Drum & Flails \\
Type & 70 \\
Diameter, $(\mathrm{cm})$ & 120 \\
Length, $(\mathrm{cm})$ & 4 \\
No. of rows & 11 \\
No. of flails / row & 120 \\
\hline Concave & 62 \\
Length, $(\mathrm{cm})$ & 20 \\
Width, $(\mathrm{cm})$ & 3 \\
No. of holes $/ 100 \mathrm{~cm}^{2}$ & 7440 \\
Concave clearance, $(\mathrm{cm})$ & 1754 \\
Area of feeding opening, $\left(\mathrm{cm}^{2}\right)$ & \\
Area of straw opening, $\left(\mathrm{cm}^{2}\right)$ & Centrifugal \\
\hline Fan & 6 \\
\hline Type & No. of blades
\end{tabular}




\section{- Performance evaluation:}

\section{1 - Machine productivity:}

The machine productivity was calculated by using the following formula according to, (Mady, 1999):

$$
P=\frac{M}{t} \ldots \ldots
$$

Where:

$\boldsymbol{P}:$ is the productivity of machine $(\mathrm{kg} / \mathrm{min})$,

$\boldsymbol{M}:$ is the mass of sample $(\mathrm{kg})$ and

$\boldsymbol{t}$ : is the time consumed in chopping operation ( $\mathrm{min}$ ).

\section{2 - Percentage of cutting length:}

Length of cutting was assessed by taking a sample of $1 \mathrm{~kg}$ from chopping onion leafs in the laboratory for separating into three categories $(<30$ $\mathrm{mm}, \geq 30-\leq 70 \mathrm{~mm}$ and $>70 \mathrm{~mm}$ ). Each category in the sample was weighed to calculate the percentage of cutting length according to the following equation, (EL- Iraqi and EL-Khawaga, 2002):

Where:

$$
L_{C}=\frac{M_{L}}{M_{C}} \times 100
$$

$$
\begin{aligned}
& \boldsymbol{L}_{\boldsymbol{C}}: \text { is the percentage of cutting length }(\%), \\
& \boldsymbol{M}_{\boldsymbol{L}}: \text { is the mass of one category }(\mathrm{g}) \text { and } \\
& \boldsymbol{M}_{\boldsymbol{C}}: \text { is the mass of total sample }(\mathrm{g}) .
\end{aligned}
$$

\section{3 - Power consumption and specific energy requirement:}

To calculate the power consumption during chopping operation of onion leafs, a consumption rate of diesel fuel ( $\mathrm{Fc}$, "L/h") was measured as follow; measuring a volume of diesel fuel required to refilling the tank after each working period of each of experiment, a graduated glass cylinder was used to measure the added quantity of diesel fuel. The power consumption in chopping operation ( $\mathrm{P}_{\mathrm{C}}$, " $\mathrm{kW}$ ") was determined experimentally for the used tractor using the following equation according to, (Embaby, 1985):

$$
P_{C}=3.163 \times F_{C}
$$

Specific energy requirement (ES " $\mathrm{kW} . \mathrm{h} / \mathrm{Mg}$ ") was calculated according to the following equation: 


$$
E_{S}=\frac{P_{C}(k W)}{\text { Machine Productivity }(M g / h)} \ldots \ldots \ldots
$$

\section{4 - Estimation costs of the used machine:}

Cost of chopping operation was calculated according to price level 2017 using the following equation given by, (Awady, 1978):

$$
\begin{aligned}
C=\frac{P}{h}\left(\frac{1}{y}+\frac{i}{2}\right. & +t+r)+(a \times f \times u)+\left(\frac{M}{144}\right)+\frac{P_{1}}{h_{1}}\left(\frac{1}{y}+\frac{i}{2}+t+r\right) \\
& +\left(\frac{M_{1}}{144}\right) \ldots \ldots \ldots(5)
\end{aligned}
$$

Where:

C : is the total hourly cost (LE/h),

$\boldsymbol{P}$ and $\boldsymbol{P}_{\mathbf{1}}$ : are the price of tractor and machine (150000 and 35000 LE), respectively,

$\boldsymbol{h}$ and $\boldsymbol{h}_{\mathbf{1}}$ : are the estimated yearly-operating hours 1000 and $750 \mathrm{~h}$ for tractor and machine, respectively,

$\boldsymbol{i} \quad$ : is the interest rate $(10 \%)$,

$\boldsymbol{y} \quad$ : is the life expectancy of machine (10 Year),

$\boldsymbol{t} \quad:$ is the taxes and overhead rates (3\%),

$\boldsymbol{r} \quad:$ is the maintenance and repairs ratio (10\%),

$\boldsymbol{a} \quad:$ is the ratio of rated power and lubrication related to fuel cost (1.2),

$f \quad:$ is the fuel consumption in $(\mathrm{L} / \mathrm{h})$,

$\boldsymbol{u}$ : is the price of diesel fuel per liter (3.65 LE),

$\boldsymbol{M}$ and $\boldsymbol{M}_{\mathbf{1}}$ : are the monthly salaries (1500 and 1000 LE) and

144 : is the estimated working hours per month.

\section{RESULTS AND DISCUSSION}

- Effect of drum speed, feeding rate and moisture content of onion residues on machine productivity.

Fig. (2) illustrates the relationship between machine productivity and drum speed at different feeding rates and two moisture contents of onion residues of 11.5 and $17.6 \%$. Generally; the obtained results showed that the machine productivity increases with increasing each of drum speed, feeding rate and moisture content of onion residues. 


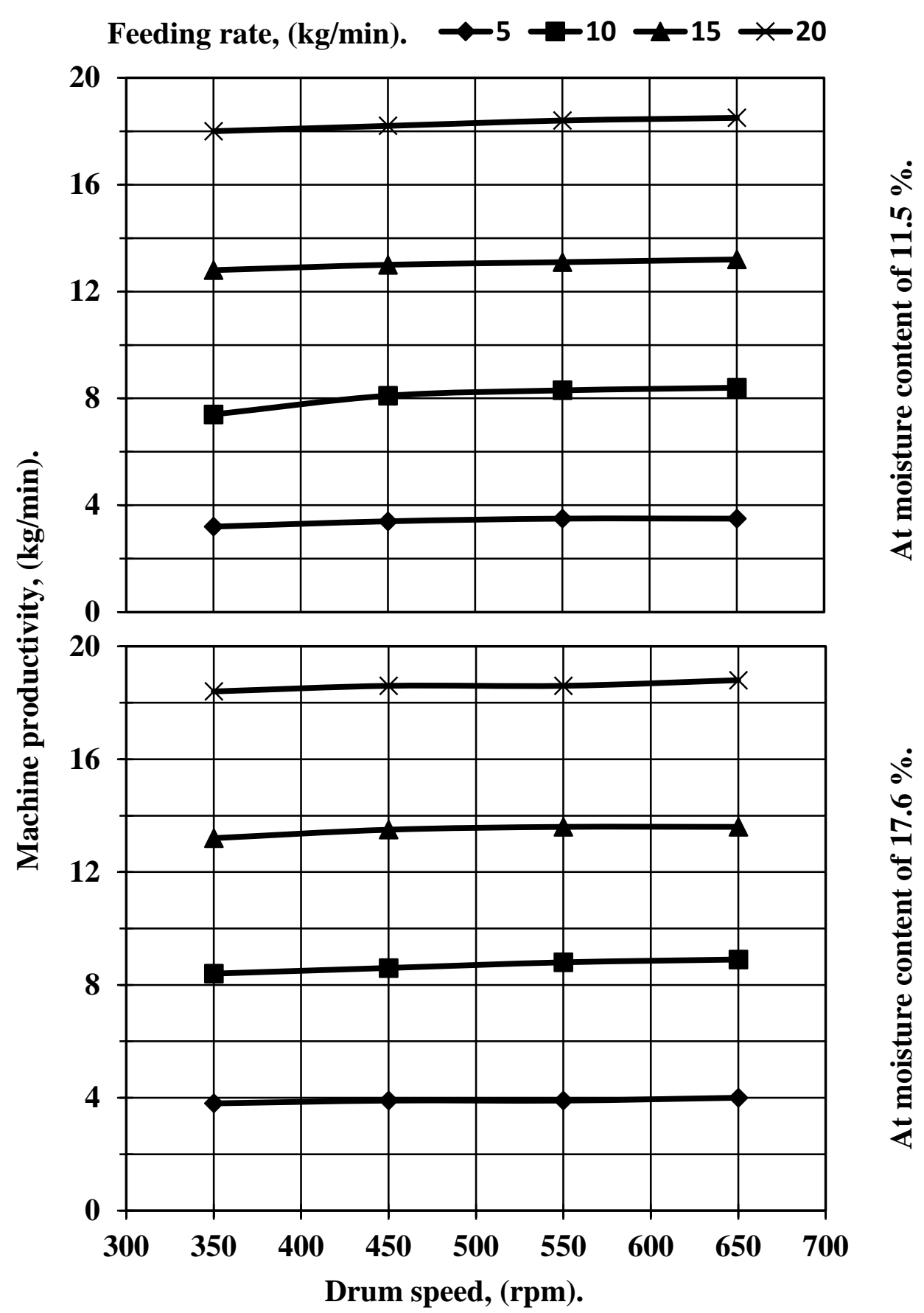

Fig. (2). Machine productivity $(\mathrm{kg} / \mathrm{min})$ versus drum speed (rpm) at different feeding rates $(\mathrm{kg} / \mathrm{min})$ and two moisture contents of onion residues $(\%)$. 
The maximum value of machine productivity was $18.8 \mathrm{~kg} / \mathrm{min}$ at drum speed of $650 \mathrm{rpm}, 20 \mathrm{~kg} / \mathrm{min}$ feeding rate and $17.6 \%$ moisture content of onion residues. While; the minimum value of machine productivity was $3.2 \mathrm{~kg} / \mathrm{min}$ at drum speed of $350 \mathrm{rpm}, 5 \mathrm{~kg} / \mathrm{min}$ feeding rate and $11.5 \%$ moisture content of onion residues.

- Effect of drum speed, feeding rate and moisture content of onion residues on specific energy requirement.

Fig. (3) shows the relationship between specific energy requirement for chopping of onion residues (leafs) and drum speed at different feeding rates and two moisture contents of onion residues of 11.5 and $17.6 \%$. The results showed that the specific energy requirement increases with increasing the speed of drum and decreases with increasing both of feeding rate and moisture content of onion residues. The maximum value of specific energy requirement was 67.7 $\mathrm{kW} . \mathrm{h} / \mathrm{Mg}$ at drum speed of $650 \mathrm{rpm}, 5 \mathrm{~kg} / \mathrm{min}$ feeding rate and $11.5 \%$ moisture content of onion residues, while; the minimum value of specific energy requirement was $10.2 \mathrm{~kW} . \mathrm{h} / \mathrm{Mg}$ at drum speed of 350 $\mathrm{rpm}, 20 \mathrm{~kg} / \mathrm{min}$ feeding rate and $17.6 \%$ moisture content of onion residues.

- Effect of drum speed, feeding rate and moisture content of onion residues on percentage of cutting length.

Fig. (4) shows the relationship between the percentage of cutting length (\%) and drum speed at different feeding rates and two moisture contents of onion residues of 11.5 and $17.6 \%$. The obtained results showed that the percentages of cutting length " $<30 \mathrm{~mm}$ " and " $\geq 30-\leq 70 \mathrm{~mm}$ " increases with increasing both of the speed of drum and moisture content of onion residues whereas; the percentages " $<30 \mathrm{~mm}$ " and " $\geq 30-\leq 70 \mathrm{~mm}$ " decreases with increasing the feeding rate. The maximum values of cutting length percentages " $<30 \mathrm{~mm}$ " and " $\geq 30-\leq 70 \mathrm{~mm}$ " were 50 and $47 \%$ at drum speed of $650 \mathrm{rpm}, 5 \mathrm{~kg} / \mathrm{min}$ feeding rate and $17.6 \%$ moisture content of onion residues, while; the minimum values of cutting length percentages were 12 and $41 \%$ at drum speed of $350 \mathrm{rpm}, 20 \mathrm{~kg} / \mathrm{min}$ feeding rate and $11.5 \%$ moisture content of onion residues, respectively. 


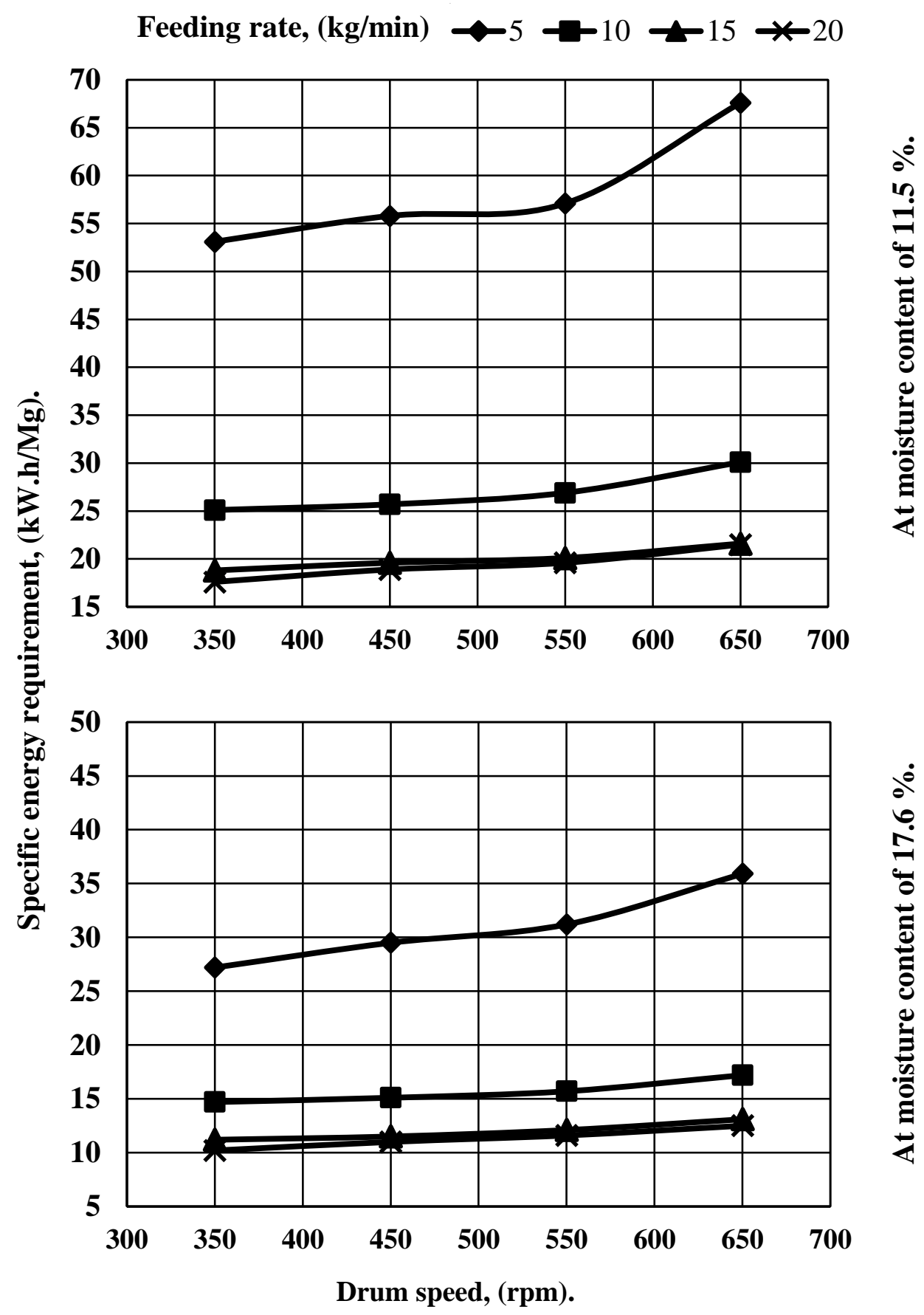

Fig. (3). Specific energy requirement (kW.h/Mg) versus drum speed $(\mathrm{rpm})$ at different feeding rates $(\mathrm{kg} / \mathrm{min})$ and two moisture contents of onion residues $(\%)$. 
At moisture content of $\mathbf{1 1 . 5} \%$

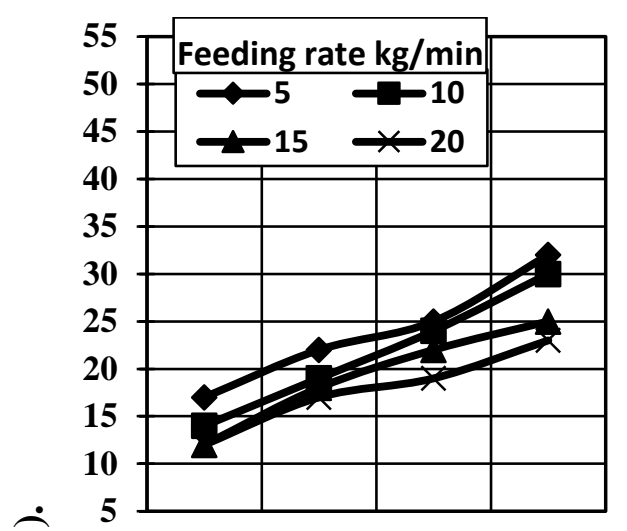

o

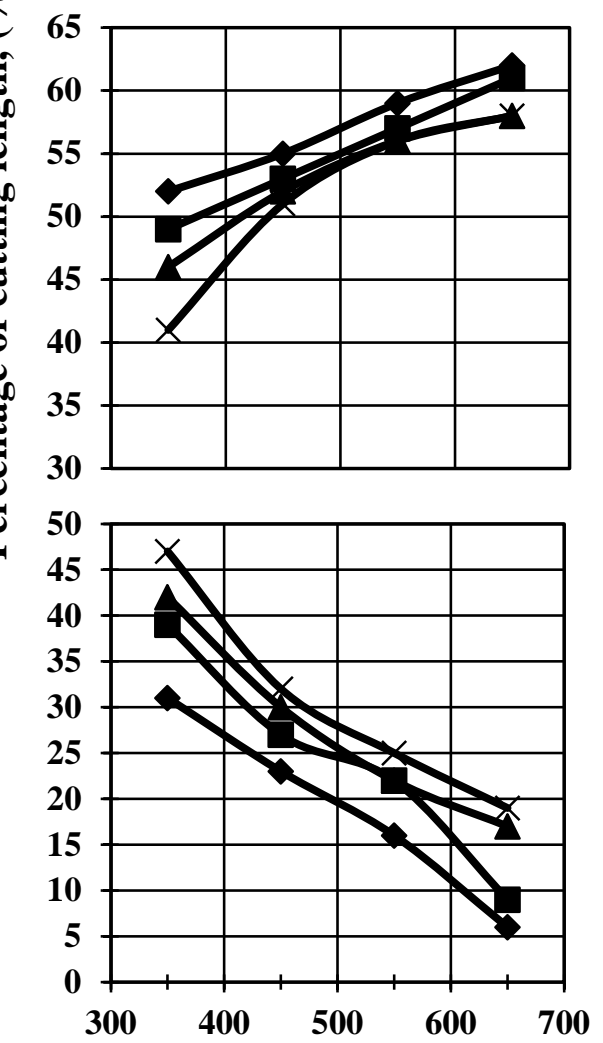

At moisture content of $\mathbf{1 7 . 6 \%}$
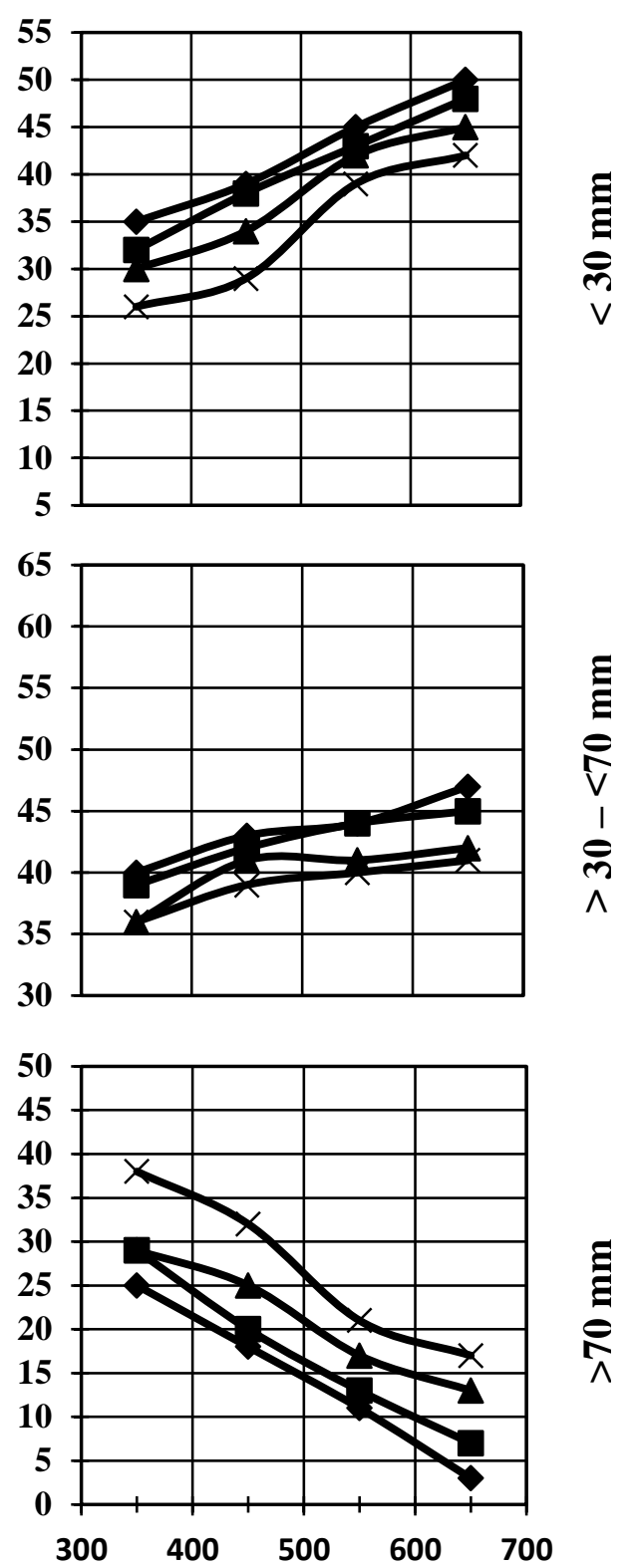

Drum speed, (rpm).

Fig. (4). Percentage of cutting length (\%) versus drum speed (rpm) at different feeding rates $(\mathrm{kg} / \mathrm{min})$ and two moisture contents of onion residues $(\%)$. 
The chopped onion residues gave the difference values of cutting length, the reason may be due to onion leafs has strong fiber, this fiber contains silicon, in addition to the difference in physical and mechanical properties of onion residues. So; the onion residues (leafs) cannot be cut easily.

\section{- Operation cost:}

The operation costs of the used machine for chopping operation of onion residues (leafs) at $20 \mathrm{~kg} / \mathrm{min}$ for feeding rate, $650 \mathrm{rpm}$ for drum speed and $17.6 \%$ moisture content of residues were $86.28 \mathrm{LE} / \mathrm{h}$ and $76.38 \mathrm{LE} / \mathrm{Mg}$.

\section{CONCLUSION}

- The main results in this study can be summarized as follows:

1) Farmers can be used the stationary threshing and separating machine in chopping of the onion residues (leafs). The cutting length of onion leafs " $<30 \mathrm{~mm}$ " can be used in feeding of animals, while; the cutting length " $\geq 30 \mathrm{~mm}$ " can be used in making of composting, according to, (Luis et al., 1993).

2) Increasing feeding rate lead to decrease the percentages of cutting length of each of " $<30 \mathrm{~mm}$ " and " $\geq 30-\leq 70 \mathrm{~mm}$ ", while; the percentage of cutting length " $>70 \mathrm{~mm}$ " increases with increasing the feeding rate for two tested moisture contents under this study.

3) Increasing drum speed lead to increase the percentages of cutting length of each of " $<30 \mathrm{~mm}$ " and " $\geq 30-\leq 70 \mathrm{~mm}$ ", while; the percentage of cutting length " $>70 \mathrm{~mm}$ " decrease with increasing the drum speed for two tested moisture contents under this study.

4) Increasing moisture content of onion residues (leafs) lead to increase the percentages of cutting length of each of " $<30 \mathrm{~mm}$ " and " $\geq 30-\leq 70 \mathrm{~mm}$ ", while; the percentage of cut length " $>70$ $\mathrm{mm}$ " decrease with increasing the moisture content of all experiments under this study.

5) The optimum conditions for chopping operating were as follow; 20 $\mathrm{kg} / \mathrm{min}$ for feeding rate and $650 \mathrm{rpm}$ for drum speed at $17.6 \%$ for moisture content, whereas the productivity of machine was 1.13 $\mathrm{Mg} / \mathrm{h}$ and the specific energy requirement was $12.5 \mathrm{~kW} . \mathrm{h} / \mathrm{Mg}$ with cost of $76.38 \mathrm{LE} / \mathrm{Mg}$. 


\section{REFRENCES}

Abd-Elrahman, M. M. and M. T. Ebaid (2009). Some factors affecting artificial curing of onion bulbs and its effects on the storability. Misr J. Ag. Eng., 26 (2): 905-919.

Arafa, G. K. (2007). Subdual of stationary thresher machine for chopping restudies. Misr J. Ag. Eng., 24 (3): 504-510.

Awady, M. N. (1978). Engineering of tractors and agricultural machinery, Text Bk., Col. Ag., Ain-Shams Univ., $5^{\text {th }}$ Ed.: 167-187. (In Arabic).

EL-Iraqi, M. and S. El-Khawaga (2002). Design and test performance of cutting machine for some crop residues (a). Misr J. Ag. Eng., 20 (1): 85-101.

Embaby, A. T. (1985). A comparison of the different mechanization systems for cereal crop production. Unpub. MSc. Thesis, Ag. Eng. Dept., Fac. of Agriculture, Cairo Univ.

FAO, (2016). Food and Agriculture Organization of the United Nations. http://www.fao.org/faostat/en/\#data/QC

Grahame, D. (2005). Production yearbook for 1990. Horticultural marketing. Food and Agriculture Organization of the united nations, Rome.

Hashish, A. E.; M. A. Hassan and A. F. Abd El-Mottalalab (1994). Some factors affecting performance of chopping, crushing and grinding equipment for field raw- material. J. Chopping grinding equipment. Misr J. Ag. Eng., 11 (3): 669-682.

Luis, F. D.; G. M. Savage; L. L. Eggerth and G. G. Clarence (1993). Composting and recycling municipal solid waste Lewis pup., London PP: 121-175.

Mady, M. A. (1999). Developing a manual cutting machine suitable for mechanical cutting stalks. Misr. J. Ag. Eng., 16 (3): 449-459.

Marita, C. (2006). Recommendations for maintaining postharvest quality. Postharvest Technology Research Information Center. Dept. of Plant Sci., Univ. of California, Davis, CA: 95616. 
Pandey, U. B.; S. R. Bhonde and V. K. Mishra (1992). Shelf life of kharif onion as influenced by curing and storage with foliage. Newsletter Associated Ag. Development Foundation., 13 (1): 5-8.

Yousf, I. S. (2005). A study on performance improvement of the local manufactured hammer mill used in polity forms., J. Ag. Sci. Mansoura Univ., 2 (11): 6827-6840.

\section{الملخص العربي}

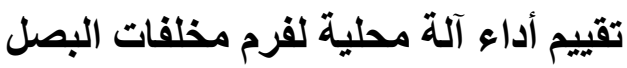

د./ رأفت علي وربي (') و د./ أحمد مصطفي موسي (r)

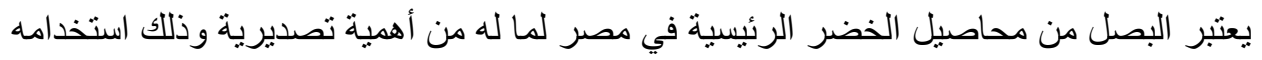

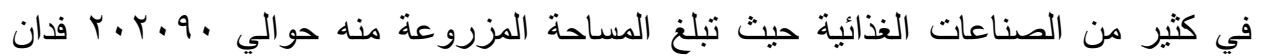

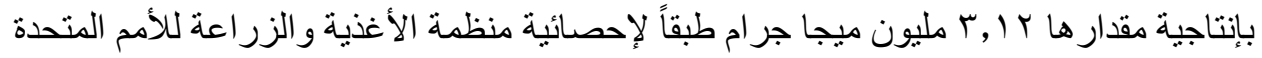

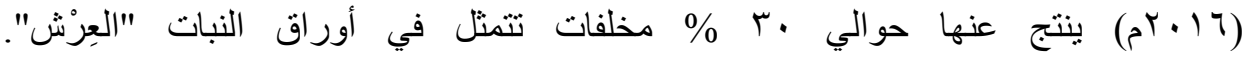

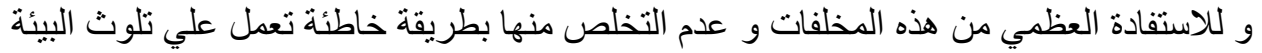

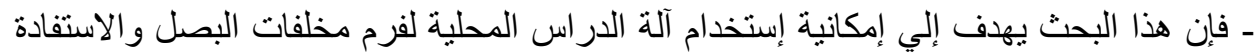

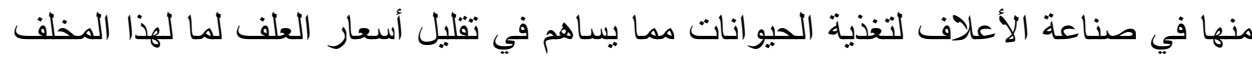

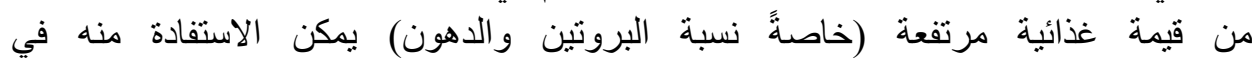

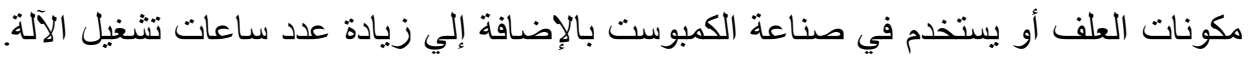

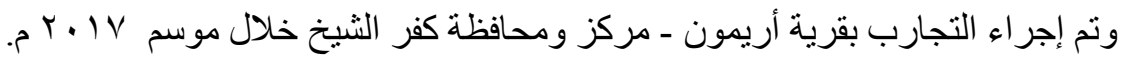

- و للوصول إلى هدف البحث تم دراسة المتغيرات التالية:

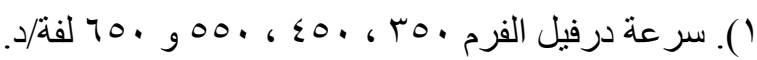

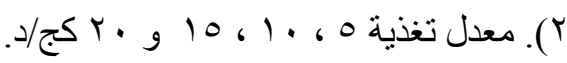

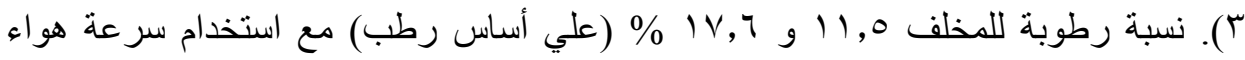

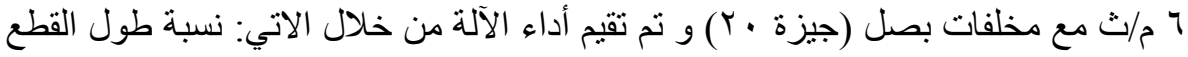
، إنتاجية الآلة ، القدرة المستهكة ، الطاقة المطلوبة للفرم و تكاليف تشغيل الآلة

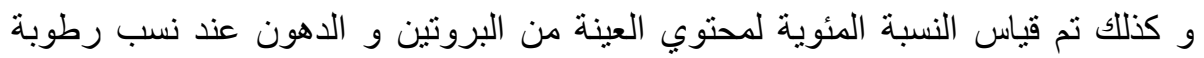
مختلفة.

(1): أستاذ مساعد و (Y): مدرس بقسم هندسة الآلات والقوي الزراعية ـ كلية الهندسة الزراعية ـ جامعة الأزهر بالقاهرة ـ مصر. 
وكاتت أهم النتائج ما يلي:

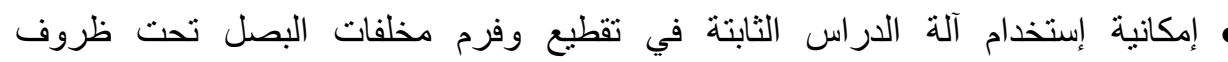

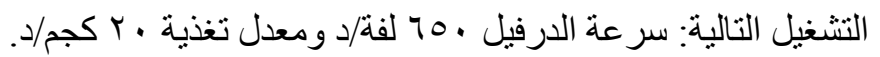

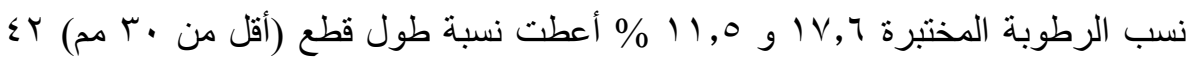

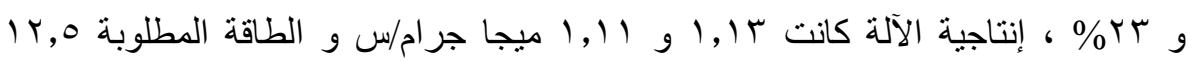
و 0, إ كيلو وات.س/ميجا جر ام علي التواليه

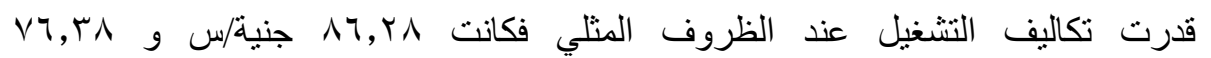
جنية/ميجاجر ام.

• أظهرت نتائج التحليل الكيميائي أن نسبتي البروتين و الدهون في مخلفات البصل عند نسبة

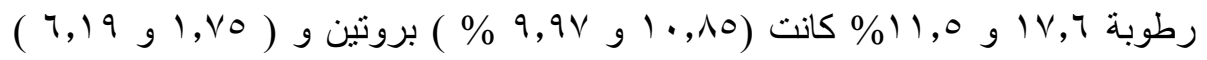
دهون على التوالي. 